\title{
ANALISIS PERBEDAAN KINERJA KEUANGAN BANK UMUM SYARIAH DENGAN BANK KONVENSIONAL DI INDONESIA (SEBUAH STUDI KOMPARATIF)
}

\author{
Dwi Vina Demetrin \\ Manajemen, Sekolah Tinggi Ilmu Ekonomi KBP Padang \\ demetrindwivina@gmail.com
}

\begin{abstract}
The purpose of this research is to analyze the difference of financial performance of sharia bank with conventional bank. Test method used in normality test using Kolomogorov Smirnov method and Independent Sample T-Test Test. The research was conducted at Bank Mandiri Syariah and Bank BRI Syariah (representing syariah bank), Bank Negara Indonesia, Bank Central Asia, Bank Tabungan Negara, Bank Bukopin, Bank Capital Indonesia, and Bank Danamon Indonesia (representing conventional bank). The financial aspect used is the ratio of CAR (Capital Adequacy Ratio), the quality of earning assets using the ratio of NPL (Non Performing Loan), rentability using ROA (Return On Assets) ratio, efficiency using BOPO ratio (Operating Expense to Operating Income), and liquidity aspect using LDR (Loan to Deposit Ratio) ratio. Based on the results of the study found that there is a significant difference between the performance of syariah banking compared with conventional banking, based on the ratio of CAR, BOPO, and LDR. While viewed from the aspect of NPL, and ROA is not significantly different syariah banking performance with conventional banking performance.
\end{abstract}

Keywords : CAR, NPL, ROA, BOPO, and LDR

\section{ABSTRAK}

Tujuan Penelitian ini adalah untuk menganalisis perbedaan kinerja keuangan Bank syariah dengan bank konvensional. Metode pengujian yang digunakan dalam penelitian uji Normalitas menggunakan metode Kolomogorov Smirnov dan Uji Independent Sample T-Test. Penelitian ini dilakukan pada Bank Mandiri Syariah dan Bank BRI Syariah (mewakili bank syariah), Bank Negara Indonesia, Bank Central Asia, Bank Tabungan Negara, Bank Bukopin, Bank Capital Indonesia, dan Bank Danamon Indonesia(mewakili bank konvensional). Aspek keuangan yang digunakan adalah rasio CAR (Capital Adequacy Ratio), kualitas aktiva produktif menggunakan rasio NPL (Non Performing Loan), rentabilitas menggunakan rasio ROA (Return On Assets), efisiensi menggunakan rasio BOPO (Beban Operasional terhadap Pendapatan Operasional), dan aspek likuiditas menggunakan rasio LDR (Loan to Deposit Ratio). Berdasarkan hasil penelitian ditemukan bahwa terdapat perbedaan yang signifikan antara kinerja perbankan syariah dibandingkan dengan perbankan konvensional, berdasarkan rasio CAR, BOPO, dan LDR. Sedangkan dilihat dari aspek $N P L$, dan ROA tidak berbeda signifikan kinerja perbankan syariah dengan kinerja perbankan konvensional.

Kata kunci : CAR, NPL, ROA, BOPO, dan LDR 


\section{PENDAHULUAN}

Pada Praktiknya, Perbankan di Indonesia saat ini berdasarkan pada kegiatan oprasionalnya terdapat 2 jenis Perbankan, yaitu Bank Konvensional dan Bank Syariah (Ardiyana,2011)(Suhartono \& Yusra, 2019). Menurut Ulya(2014), Bank Konvensional yaitu dimana suatu perbankan Operasionalnya menerapkan metode Bunga, karena metode bunga sudah ada terlebih dahulu dipakai dibandingkan dengan metode bagi hasil. Sedangkan menurut Ningsih(2012), Bank Syariah yaitu suatu perbankan yang berdasarkan sesuai dengan prinsip syariah. yang artinya menghimpun dana dari masyarakat gunanya untuk di salurkan kembali ke pada masyarakat. Oleh Karena itu, dapat disimpulkan bahwa Bank Syariah yaitu Bank yang mengikuti sesuai syariah islam artinya berlandasan sesuai dengan alquran dan hadis.

Bank konvensional pada umumnya menyerap dana masyarakat berupa tabungan, deposito, dan simpangan giro, dan setelah itu menyalurkan dana tersebut dalam bentuk kredit. (Ulya, 2014). Oleh Karena itu dapat disimpulkan bahwa Bank Konvensional adalah Bank yang pertama sekali beroperasi di Indonesia di bandingkan dengan Bank Syariah dan sudah memberikan nama yang baik pada masyarakat.

Perbankan syariah atau yang disebut dengan Perbankan Islam merupakan suatu sistem perbankan yang dikembangkan syariah dengan tata cara pengoperasiannya berdasarkan bermuamalah secara Islam, sesuai Al-Qur'an dan Al-Hadits Ulya (2014). Oleh Karena itu dapat disimpulkan bahwa Bank Syariah adalah Bank yang mengikuti semua ketentuan berdasarkan ajarah islam yang berpedoman pada syariah-syariah islam.

Kinerja keuangan artinya suatu aktivitas yang dilakukan oleh perusahaan demi menghasilkan keuntungan secara efesien dan efektif, gambaran ini mencakup tentang bagaimana setiap hasil terhadap ekonomi mampu dicapai suatu perusahaan perbankan pada saat periode tertentu. (Marissa,2011)(Mulfita \& Yusra, 2019; Putra \& Yusra, 2019; Yusra, 2016; Yusra, Hadya, \& Fernandes, 2017). Dengan demikian dapat disimpulkan bahwa Kinerja Keuangan merupakan suatu perbankan yang dapat melakukan penilaian kinerja perusahaan sebagai pengambilan keputusan dengan melakukan analisis-analisis keuangan baik dan buruknya keadaan keuangan perbankan.

Dengan terdapat adanya perbedaan antara Bank Syariah juga Bank Konvensional saling bersaing untuk menjadi pilihan di kalangan masyarakat. hal itu membuktikan bahwa bank konvensional lebih dikenal oleh masyarakat dibandingkan dengan bank syariah. Hal ini menjadi tantangan bagi Bank Syariah untuk dapat mengembangkan kelebihan yang ada dibandingkan dengan Bank Konvensional sehingga masyarakat tertarik menjadi nasabah Bank Syariah (Ulya,2014). Selain itu, Bank Konvensional dan juga Bank Syariah bisa dikatakan sama. karena dalam segi pelayanan bank konvensional lebih dulu menciptakan jasa-jasa yang menarik para nasabah dibanding dengan bank syariah.

Sabir, Ali \& Habbe (2012) melakukan Perbandingan antara Bank Syariah dan Bank Konvensional, Bank Syariah menggunakan Sistem bagi hasil perbankan syariah yang diterapkan suatu bank tersebut mereka lebih dominan dalam mempertahankan kinerjanya dengan tujuan dalam peningkatan yang terjadi pada suku bunga dampaknya beban operasional lebih mengalami penurunan dibandingkan pada Bank Konvensinal. Fungsi Intermediasi secara umum yang terdapat pada bank syariah tentu mengalami pertumbuhan dana yang dihimpun ataupun pembiayaan yang relatif mengalami peningkatan dibandingkan pada perbankan nasional, di dukungnya penyediaan akses 
jaringan yang mengalami peningkatan dan mempermudah masyarakat dalam menjangkaunya. Dampaknya Positif nya bagi Bank Syariah memiliki kinerja keuangan yang jauh lebih baik. Sedangkan bagi perbankan konvensional, adanya selisih karena besarnya bunga yang dikenakan debitur artinya dengan imbalan suatu bunga kepada nasabah. Dengan adanya imbalan tersebut tentu menjadi keuntungan yang besar bagi perbankan, sehingga pendapatan tersebut dapat mempengaruhi kinerja keuangan perbankan konvensional. Hal inilah yang membedakan dalam peningkatan dari segi kinerja keuangannya antara Bank Syariah dengan Bank Umum Konvensional apabila dilihat dari Rasio Keuangan yang digunakan.

Pada Penelitian Terdahulu melakukan penelitian tentang perbandingan kinerja keuangan bank syariah dan bank konvensional, misalkan pada temuan Ari \& Setyaningsih (2013), Dalam penelitian ini menggunakan Bank Muamalat sebagai Bank Syariah dan Bank Rakyat Indonesia. adapun Sumber data yang digunakan adalah berupa data sekunder. Artinya menggunakan teknik pengumpulan data yaitu secara dokumentasi. Adapun Rasio yang digunakan dalam penelitian ini adalah menggunakan variabel CAR, NPL, ROA, BOPO, dan LDR.

Pada penelitian Nuresya (2008) Mengatakan Bahwa Kinerja Keuangan Bank Umum Konvensinal dan Bank Syariah menunjukkan terdapat perbedaan nilai CAR saling berkolerasi dan signfikan. Artinya rasio CAR mempunyai kecukupan modal yang berfungsi menampung risiko kerugian yang kemungkinan dihadapi oleh bank. Semakin tinggi CAR maka semakin baik kemampuan bank tersebut untuk menanggung risiko dari setiap kredit Atau aktiva produktif yang berisiko

Begitu juga pada temuan Marissa (2011) mengatakan bahwa Kinerja Keuangan Bank Umum Konvensional dan Bank Syariah menunjukkan bahwa terdapat perbedaan nilai BOPO, dan LDR. Berbedanya nilai BOPO dapat ditingkatkan kualitasnya dengan menekan biaya operasional dan meningkatkan pendapatan operasional. artinya semakin BOPO yang kecil menunjukkan bahwa biaya operasional bank juga akan lebih kecil dari pendapatan operasionalnya. Dengan hal demikian artinya menunjukkan bahwa manajemen bank lebih efektif dan efisien dalam menjalankan aktivitas operasionalnya. Berbedanya nilai LDR juga dilihat dari Pihak bank yang harus menilai calon debitur yang mempunyai karakter kuat, kemampuan mengembalikan uang, jaminan yang berharga, di dukung dengan modal yang kuat, serta kondisi perekonomian yang aman. Oleh karena itu, dapat disimpulkan apabila nilai LDR mengalami peningkatan akan menunjukkan bahwa jumlah kredit yang disalurkan lebih besar dari dana pihak ketiga.

Pada Penelitian sebelumnya bertolak belakang dengan Penelitian yang dilakukan Bambang (2008), mengatakan bahwa Bank Umum Konvensional dan Bank Syariah dilihat dari rasio NPL, dan ROA yang menunjukkan bahwa tidak terdapat perbedaan yang signifikan pada Bank Umum Konvensional dan Bank Syariah. Artinya tidak terjadi perbedaan antara Bank Umum Konvensional dengan Bank Syariah karena kecilnya resiko kredit yang ditanggung oleh pihak Bank, karena tidak terjadinya masalah yang mengenai dalam jumlah pembiayaan atau kredit.

\section{METODE PENELITIAN}

Penelitian ini Deskriptif Kuantitatif yaitu suatu penelitian yang menjelaskan menggambarkan suatu fenomena yang ada dengan menggunakan angka-angka (Suryani, 2015). Dalam hal ini peneliti menggunakan suatu lembaga keuangan perbankan yang terdaftar di ISSI dan BEI sebagai objek pengamatan. Bursa Efek Indonesia atau yang 
dikenal BEI merupakan salah satu penyampaian informasi kelengkapan pengungkapan laporan keuangan bulanan atau tahunan pada setiap jenis perusahan. Sedangkan ISSI merupakan penyampaian informasi laporan keuangan perusahaan yang berprinsip syariah hampir sama dengan BEI. Jumlah Populasi pada sektor ini adalah sebanyak 30 Pada Bank Umum Konvensional, dan Bank Syariah. Pemilihan Sampel dilakukan dengan menggunakan teknik Purpose Sampling, dimana diperoleh 6 Perusahaan Untuk Bank Umum Konvensional, dan 2 Perusahaan Untuk Bank Syariah dengan kriteria: Kriteria yaitu: Bank Terdaftar di Bursa Efek Indonesia 2012-2016, dan Indeks Saham Syariah Indonesia Selama Periode Pengamatan, Mempunyai Laporan Keuangan yang di lengkap, dan Memiliki data yang sesuai dengan Variabel yang dibutuhkan.

Tabel 1.

\section{Definisi Operasional Variabel Penelitian}

\begin{tabular}{|c|c|c|c|}
\hline No & Variabel & Definisi & Pengukuran \\
\hline 1. & CAR & $\begin{array}{l}\text { CAR bagaimana mengenai } \\
\text { kecukupan modal yang } \\
\text { dimiliki bank tersebut demi } \\
\text { menunjang aktiva yang dapat } \\
\text { menimbulkan resiko, misalnya } \\
\text { kredit yang diberikan } \\
\text { (Nuresya,2008) }\end{array}$ & $C A R=\frac{\text { Modal Bank }}{\text { Aktiva Tertimbang }} \times 100 \%$ \\
\hline 2. & NPL & $\begin{array}{l}\text { NPL (Non Performing Loan) } \\
\text { artinya dimana debiturnya } \\
\text { tidak memenuhi persyaratan } \\
\text { yang diperjanjikan artinya } \\
\text { kredit tersebut tidak lancar } \\
\text { atau macet (Nuresya,2008). }\end{array}$ & $N P L=\frac{\text { Kredit Bermasalah }}{\text { Total Kredit }} \times 100 \%$ \\
\hline 3. & ROA & $\begin{array}{l}\text { ROA (Return on Assets), yaitu } \\
\text { bagaimana manajemen bank } \\
\text { bia mengukur untuk } \\
\text { mendapatkan keuntungan } \\
\text { (laba) dari. Semakin baik nilai } \\
\text { ROA maka akan semakin } \\
\text { bagus posisi bank tersebut } \\
\text { (Nuresya, 2008). }\end{array}$ & $R O A=\frac{\text { Laba Sebelum Pajak }}{\text { Total Aktiva }} \times 100 \%$ \\
\hline
\end{tabular}




\begin{tabular}{|c|c|c|c|}
\hline No & Variabel & Definisi & Pengukuran \\
\hline 4. & BOPO & $\begin{array}{lr}\text { BOPO (Rasio } & \text { Biaya } \\
\text { Operasional),suatu } & \\
\text { perbandingan } & \text { dimana } \\
\text { pendapatan } & \text { operasional } \\
\text { dengan biaya } & \text { operasional. } \\
\text { Artinya Rasio ini digunakan } \\
\text { bagaimana mengukur tingkat } \\
\text { efisiensi dan kemampuan } \\
\text { bank dalam } & \text { melakukan } \\
\text { kegiatan } & \text { operasinya } \\
\text { (Nuresya,2008). }\end{array}$ & $B O P O=\frac{\text { Beban Operasional }}{\text { Pendapatan Operasional }} \times 100 \%$ \\
\hline 5. & LDR & $\begin{array}{l}\text { LDR (Loan to Deposit Ratio) } \\
\text { semua jumlah kredit yang } \\
\text { diberikan bank dengan dana } \\
\text { yang diterima bank misalnya } \\
\text { dana yang diterima dari pihak } \\
\text { luar (Nuresya,2008). }\end{array}$ & $L D R=\frac{\text { Jumla Kredit yang diberikan }}{\text { Total Dana Pihak Ketiga }} \times 100 \%$ \\
\hline
\end{tabular}

Penelitian ini menggunakan Teknik Analisis Data Statistik Deskriptif yaitu mendeskripsikan dengan memberi gambaran terhadap obyek yang diteliti yaitu dengan melalui data sampel atau populasi (Sugiyono, 2015). Dalam penelitian ini menggunakan Analisis statistik deskriptif terhadap rasio keuangan yang digunakan dengan menjelaskan hasil dari nilai tertinggi, nilai terendah, rata-rata, dan hasil terhadap standar deviasi, dari variabel yang diteliti.

Pada penelitian ini dalam melakukan Pengolahan data menggunakan Uji Beda Rata-rata tujuannya adalah bagaimana membandingkan kinerja keuangan Bank Syariah dengan Bank Umum Konvensional dengan menggunakan uji statistik beda rata-rata yang dengan (independent sample t-test).Yang dimaksud dengan Independent-Sample $t$ test artinya membandingkan bagaimana suatu perbedaan dari rata-rata di antara dua kelompok data yang tidak saling berhubungan. Idealnya, untuk tes ini subjek harus secara dipilih untuk dua kelompok (Suryani,2015). Juga melakukan uji normalitas untuk memberikan kepastian data berdistribusi normal atau tidak dengan menggunakan metode kolmogorov smirnov. 
HASIL DAN PEMBAHASAN

Tabel 2.

Descriptive Statistic Rasio Keuangan Bank Umum Konvesnional

\begin{tabular}{|l|c|c|c|c|}
\hline \multirow{2}{*}{ Rasio } & \multicolumn{4}{|c|}{ Bank Umum Konvensional } \\
\cline { 2 - 5 } & Mean & Max & Min & $\begin{array}{c}\text { Standar } \\
\text { Devisiasi }\end{array}$ \\
\hline CAR & 0.0384 & 0.0839 & 0.0117 & 0.0187 \\
\hline NPL & 0.0235 & 0.0653 & 0.0031 & 0.0139 \\
\hline ROA & 0.0221 & 0.0341 & 0.0079 & 0.0088 \\
\hline BOPO & 0.0156 & 0.0156 & 0.0156 & 0.0000 \\
\hline LDR & 0.0208 & 0.0759 & 0.0012 & 0.0213 \\
\hline
\end{tabular}

Sumber: Data diolah Peneliti

Tabel 3.

Descriptive Statistic Rasio Keuangan Bank Syariah

\begin{tabular}{|l|c|c|c|c|}
\hline \multirow{2}{*}{ Rasio } & \multicolumn{4}{|c|}{ Bank Syariah } \\
\cline { 2 - 5 } & Mean & Max & Min & $\begin{array}{c}\text { Standar } \\
\text { Devisiasi }\end{array}$ \\
\hline CAR & 0.0768 & 0.1412 & 0.0114 & 0.0641 \\
\hline NPL & 0.0561 & 0.0982 & 0.0110 & 0.0286 \\
\hline ROA & 0.0527 & 0.0940 & 0.0140 & 0.0276 \\
\hline BOPO & 0.4550 & 0.9849 & 0.0167 & 0.4628 \\
\hline LDR & 0.4537 & 0.9440 & 0.0314 & 0.4382 \\
\hline
\end{tabular}

Sumber: Data diolah Peneliti 
Tabel 4.

Hasil Uji Normalitas Metode One-Sample Kolmogorov Smirnov Bank Umum Konvensional

One-Sample Kolmogorov-Smirnov Test

\begin{tabular}{|ll|r|r|r|r|r|}
\hline & & CAR & NPL & ROA & BOPO & LDR \\
\hline N & & 30 & 30 & 30 & 30 & 30 \\
Normal & Mean & -3.3856 & -3.9434 & -3.9114 & -3.4504 & -4.3743 \\
& Std. Deviation & .52841 & .68843 & .47629 & .51771 & 1.0919 \\
& & & & & & 5 \\
Most Extreme & Absolute & .102 & .130 & .242 & .138 & .114 \\
Differences & Positive & .061 & .065 & .132 & .105 & .078 \\
& Negative & -.102 & -.130 & -.242 & -.138 & -.114 \\
& & .558 & .713 & 1.325 & .754 & .624 \\
& .914 & .689 & .060 & .621 & .831 \\
\hline
\end{tabular}

Pada Tabel di atas bahwa terlihat dari bahwa Hasil Uji Normalitas menggunakan metode Kolmogorov Smirnov pada Bank Umum Konvensional diperoleh nilai Asymp. Sig yang lebih besar dari Alpha. Dengan demikian, dapat disimpulkan bahwa rasio keuangan CAR 0.914, NPL 0.689, ROA 0.06, BOPO 0.621, dan LDR 0.831. artinya rasio keuangan pada Bank Umum Konvensional dapat dikatakan berdistribusi normal. Karena melebihi Standar dari Alpha 0.05. 
Tabel 5.

Hasil Uji Normalitas Metode One-Sample Kolmogorov Smirnov Bank Syariah

One-Sample Kolmogorov-Smirnov Test

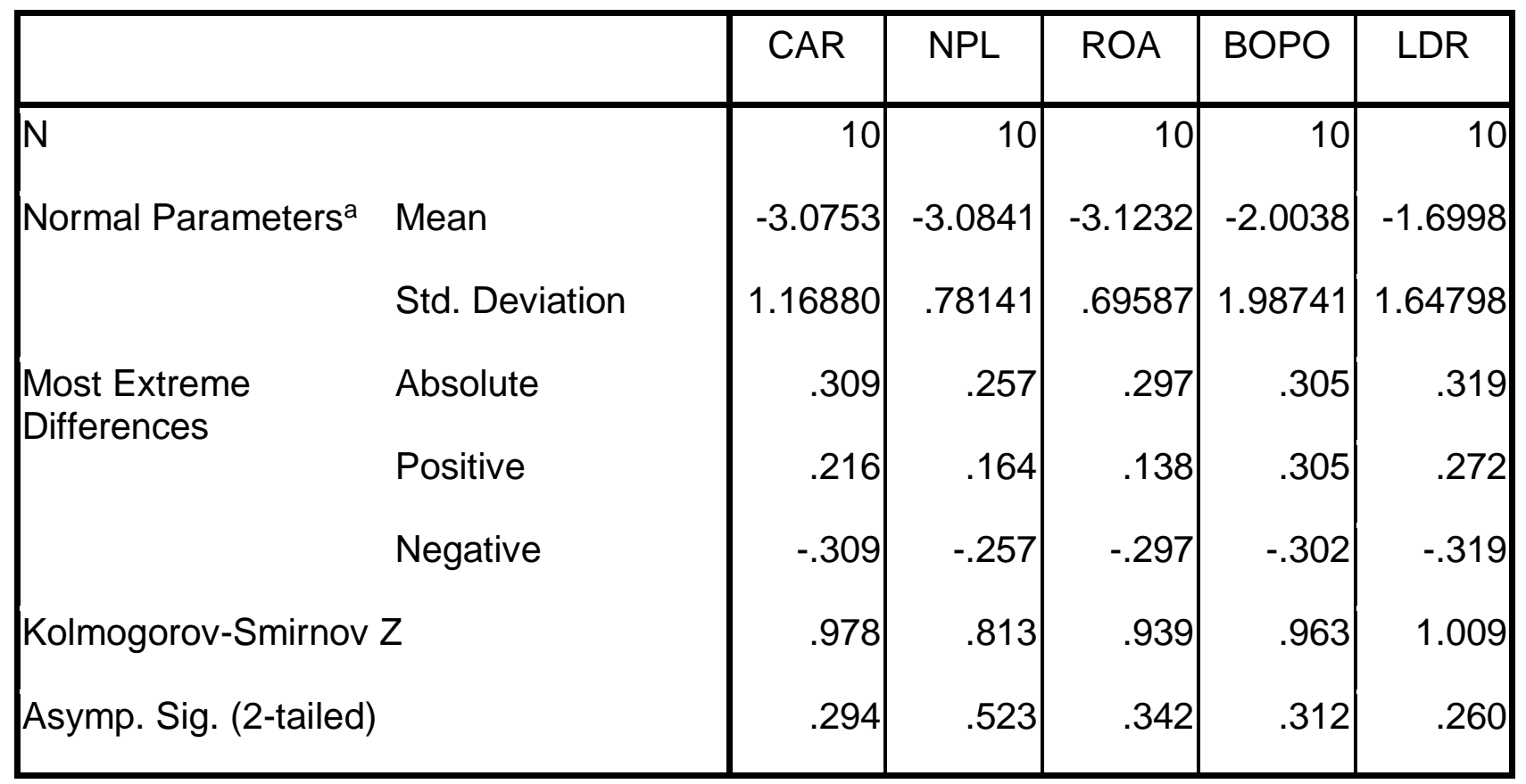

Pada Tabel di atas terlihat bahwa Hasil Uji Normalitas menggunakan metode Kolmogorov Smirnov pada Bank Syariah diperoleh nilai Asymp. Sig yang lebih besar dari Alpha. Dengan demikian, dapat disimpulkan bahwa rasio keuangan CAR 0.294, NPL 0.523, ROA 0.342, BOPO 0.312, dan LDR 0.260. artinya rasio keuangan pada Bank Syariah dapat dikatakan berdistribusi normal. Karena melebihi Standar dari Alpha 0.05 . 
Tabel 6.

Hasil Uji Statistik Independet Sample t-Test Rasio CAR, NPL, ROA, BOPO, dan LDR

Independent Samples Test

\begin{tabular}{|c|c|c|c|c|c|c|c|c|c|c|}
\hline & \multicolumn{2}{|c|}{$\begin{array}{l}\text { Levene's Test } \\
\text { for Equality of } \\
\text { Variances }\end{array}$} & \multicolumn{7}{|c|}{ t-test for Equality of Means } \\
\hline & & \multirow[b]{2}{*}{$\mathrm{F}$} & \multirow[b]{2}{*}{ Sig. } & \multirow[b]{2}{*}{$t$} & \multirow[b]{2}{*}{ df } & \multirow{2}{*}{$\begin{array}{c}\text { Sig. } \\
(2- \\
\text { tailed })\end{array}$} & \multirow{2}{*}{$\begin{array}{c}\text { Mean } \\
\text { Difference }\end{array}$} & \multirow{2}{*}{$\begin{array}{l}\text { Std. } \\
\text { Error } \\
\text { Differenc } \\
\quad \text { e } \\
\end{array}$} & \multicolumn{2}{|c|}{$\begin{array}{l}95 \% \text { Confidence } \\
\text { Interval of the } \\
\text { Difference }\end{array}$} \\
\hline & & & & & & & & & Lower & Upper \\
\hline \multirow[t]{2}{*}{ CAR } & $\begin{array}{l}\text { Equal variances } \\
\text { assumed }\end{array}$ & \multirow[t]{2}{*}{41.304} & \multirow[t]{2}{*}{.000} & \multirow[t]{2}{*}{-1.16} & \multirow{2}{*}{$\begin{array}{r}38 \\
10.253\end{array}$} & \multirow{2}{*}{$\begin{array}{l}.253 \\
.435 \\
\end{array}$} & \multirow{2}{*}{$\begin{array}{l}-.3102997 \\
-.3102997 \\
\end{array}$} & \multirow{2}{*}{$\begin{array}{r}.2674912 \\
.3819912 \\
\end{array}$} & \multirow{2}{*}{$\begin{array}{r}-.8518074 \\
-1.1585872 \\
\end{array}$} & \multirow{2}{*}{$\begin{array}{l}.2312080 \\
.5379878\end{array}$} \\
\hline & $\begin{array}{l}\text { Equal variances not } \\
\text { assumed }\end{array}$ & & & & & & & & & \\
\hline \multirow[t]{2}{*}{ NPL } & $\begin{array}{l}\text { Equal variances } \\
\text { assumed }\end{array}$ & \multirow[t]{2}{*}{.163} & \multirow[t]{2}{*}{.689} & \multirow{2}{*}{$\begin{array}{l}-3.307 \\
-3.099\end{array}$} & \multirow{2}{*}{$\begin{array}{r}38 \\
13.969 \\
\end{array}$} & \multirow{2}{*}{$\begin{array}{l}.002 \\
.008\end{array}$} & \multirow{2}{*}{$\begin{array}{l}-.8592681 \\
-.8592681\end{array}$} & \multirow{2}{*}{$\begin{array}{r}.2598230 \\
.2772338 \\
\end{array}$} & \multirow{2}{*}{$\begin{array}{l}-1.3852522 \\
-1.4539977\end{array}$} & \multirow{2}{*}{$\begin{array}{r}.3332839 \\
. \\
.2645385 \\
\end{array}$} \\
\hline & $\begin{array}{l}\text { Equal variances not } \\
\text { assumed }\end{array}$ & & & & & & & & & \\
\hline \multirow[t]{2}{*}{$\mathrm{ROA}$} & $\begin{array}{l}\text { Equal variances } \\
\text { assumed }\end{array}$ & \multirow[t]{2}{*}{2.896} & \multirow[t]{2}{*}{.097} & \multirow{2}{*}{$\begin{array}{l}-4.023 \\
-3.331\end{array}$} & \multirow{2}{*}{$\begin{array}{r}38 \\
11.940\end{array}$} & \multirow{2}{*}{$\begin{array}{l}.000 \\
.006\end{array}$} & \multirow{2}{*}{$\left|\begin{array}{l}-.7881445 \\
-.7881445\end{array}\right|$} & .1958950 & -1.1847132 & .3915758 \\
\hline & $\begin{array}{l}\text { Equal variances not } \\
\text { assumed }\end{array}$ & & & & & & & .2366120 & -1.3039654 & .2723236 \\
\hline BOPO & $\begin{array}{l}\text { Equal variances } \\
\text { assumed }\end{array}$ & 305.860 & .000 & -3.710 & 38 & .001 & 1.4465583 & .3898756 & -2.2358202 & .6572964 \\
\hline & $\begin{array}{l}\text { Equal variances not } \\
\text { assumed }\end{array}$ & & & -2.276 & 9.410 & .048 & $1.4465583^{-}$ & .6355429 & -2.8747584 & .0183582 \\
\hline LDR & $\begin{array}{l}\text { Equal variances } \\
\text { assumed }\end{array}$ & 10.853 & .002 & -5.877 & 38 & .000 & 2.6744250 & .4550706 & -3.5956672 & $\begin{array}{r}1.753182 \\
8\end{array}$ \\
\hline & $\begin{array}{l}\text { Equal variances not } \\
\text { assumed }\end{array}$ & & & -4.793 & 11.749 & .000 & 2.6744250 & .5579670 & -3.8930188 & $\begin{array}{r}1.455831 \\
2\end{array}$ \\
\hline
\end{tabular}

Secara Umum, Tabel 6 menunjukkan bahwa terdapat perbedaan kinerja keuangan Bank Umum Konvensional dan Bank Syariah ditinjau dari indikator keuangan yang digunakan dalam penelitian. Secara Statistik perbedaan tersebut terlihat dari nilai Sig untuk CAR, NPL, ROA, BOPO, dan LDR lebih kecil dari level of signifikan (Sig < 0,05). Secara Spesifik, nilai signifikan untuk CAR sebesar 0.000, NPL sebesar 0.689, ROA sebesar 0.097, BOPO sebesar 0.000, dan LDR sebesar 0.002. kecilnya nilai Sig 
dari Alpha mengindikasikan bahwa nilai rata-rata rasio keuangan Bank Umum

Konvensional berbeda signifikan dengan rata-rata rasio Keuangan Bank Syariah.

\section{KESIMPULAN DAN SARAN}

\section{KESIMPULAN}

Berdasarkan hasil dan pembahasan yang mengacu pada masalah dan tujuan Penelitian, maka dapat disimpulkan sebagai berikut :

1. Kinerja Keuangan Bank Umum Konvensional (di proxy dengan CAR, BOPO, dan LDR) berbeda secara Sign dengan Kinerja Keuangan Bank Syariah.

2. Kinerja Keuangan Bank Umum Konvensional (di proxy dengan NPL, dan ROA) tidak berbeda secara Sign dengan Kinerja Keuangan Bank Syariah.

\section{SARAN}

Dari Hasil Kesimpulan dalam penelitian ini, penulis memberikan saran sebagai berikut:

1. Periode Pengamatan pada penelitian ini hanya lima tahun yaitu tahun 2012-2016. Untuk Penelitian yang akan datang sebaiknya menambah jumlah periode pengamatan untuk mendapatkan hasil yang lebih korprehensif.

2. Bagi Penelitian yang akan datang, sebaiknya menambah rasio keuangan lain. Misalnya, menggunakan ROE dan NPM (Eko,2014; Ibrahim,2017).

3. Bagi Peneliti yang akan datang, sebaiknya memperluas objek penelitian lain, tidak hanya pada perusahaan perbankan saja, tetapi juga pada perusahaan atau industri lain, sehingga hasil penelitian dapat digeneralisasi.

\section{UCAPAN TERIMAKASIH}

Skripsi ini diajukan sebagai salah satu syarat untuk menyelesaikan program studi S1 Manajemen STIE "KBP" Padang. Dalam penyusunan Skripsi ini Peneliti banyak memperoleh bantuan, bimbingan dan arahan yang sangat bermanfaat dari berbagai pihak. Oleh karena itu pada kesempatan ini peneliti mengucapkan terima kasih kepada Yth:

1. Bapak Febryandhie Ananda, SE, MSi selaku ketua STIE ''KBP', Padang

2. Ibu Febsri Susanti, SEI,MM selaku ketua Program Studi Manajemen yang telah mengarahkan penulis kepada yang lebih baik

3. Ibu Maria Magdalena, S.Pd., MM selaku Pembimbing Akademik yang telah memberikan bimbingan dan arahan kepada penulis

4. Bapak Irdha Yusra, SE,M.Sc. selaku Pembimbing Proposal yang telah memberikan izin kepada peneliti untuk pengambilan dan pengumpulan data dalam penelitian ini.

\section{DAFTAR PUSTAKA}

Ari, \& Setyaningsih. (2013). Analisis Perbandingan Kinerja Keuangan Perbankan Syariah Dengan Perbankan Konvensional, 13(1), 100-115.

Bambang Sudiyatno, J. S. (2008). Analisis Pengaruh Dana Pihak Ketiga, BOPO, CAR, Dan

LDR Terhadap Kinerja Keuangan Pada Sektor Perbankan Yang Go Public Di Bursa Efek Indonesi, 2, 125-137. 
Eko, Sri, D. (2014). Analisis Posisi Kinerja Keuangan Antara Bank Syariah dan Bank Konvensional Di Indonesia, 2(4), 258-268.

Marissa Ardiyana. (2011). KEUANGAN BANK SYARI’'AH DAN BANK KONVENSIONAL SEBELUM, SELAMA, DAN.

Mulfita, A., \& Yusra, I. (2019). Analisis regresi data panel terhadap likuiditas saham di Indonesia. INA-Rxiv.

Ningsih, widya wahyu. (2012). Analisis perbandingan kinerja keuangan bank umum syariah dengan bank umum konvensional di indonesia skripsi.

Nuresya Meliyanti. (2008). Analisis Kinerja Keuangan Bank : Pendekatan Rasio NPL, LDR, BOPO DAN ROA Pada Bank Privat Dan Publik, 1-14.

Putra, A. D., \& Yusra, I. (2019). Peran profitabilitas dalam memoderasi pengaruh free cash flow terhadap kebijakan dividen di Indonesia. INA-Rxiv.

Suhartono, \& Yusra, I. (2019). Analisis perbandingan kinerja keuangan bank konvensional dengan bank syariah yang terdaftar di BEI. INA-Rxiv, 1-9.

Ulya, N. I. (2014). EARNINGS DAN CAPITAL PRODI KEUANGAN ISLAM FAKULTAS SYARI' AH DAN HUKUM UNIVERSITAS ISLAM NEGERI SUNAN KALIJAGA.

Yusra, I. (2016). Kemampuan Rasio Likuiditas dan Solvabilitas dalam Memprediksi Laba Perusahaan: Studi Empiris pada Perusahaan Telekomunikasi yang Terdaftar di Bursa Efek Indonesia. Jurnal Benefita, 1(1), 33-42. https://doi.org/http://dx.doi.org/10.22216/jbe.v1i1.878

Yusra, I., Hadya, R., \& Fernandes, J. (2017). Likuiditas , financial leverage , dan prediktabilitas beta: pendekatan Fowler and Rorke sebagai metode koreksi Beta. Jurnal Benefita, 2(1), 81-91.

Ari, \& Setyaningsih. (2013). Analisis Perbandingan Kinerja Keuangan Perbankan Syariah Dengan Perbankan Konvensional, 13(1), 100-115.

Bambang Sudiyatno, J. S. (2008). Analisis Pengaruh Dana Pihak Ketiga, BOPO, CAR, Dan LDR Terhadap Kinerja Keuangan Pada Sektor Perbankan Yang Go Public Di Bursa Efek Indonesi, 2, 125-137.

Eko, Sri, D. (2014). Analisis Posisi Kinerja Keuangan Antara Bank Syariah dan Bank Konvensional Di Indonesia, 2(4), 258-268.

Marissa Ardiyana. (2011). KEUANGAN BANK SYARI' AH DAN BANK KONVENSIONAL SEBELUM, SELAMA, DAN.

Mulfita, A., \& Yusra, I. (2019). Analisis regresi data panel terhadap likuiditas saham di Indonesia. INA-Rxiv.

Ningsih, widya wahyu. (2012). Analisis perbandingan kinerja keuangan bank umum syariah dengan bank umum konvensional di indonesia skripsi.

Nuresya Meliyanti. (2008). Analisis Kinerja Keuangan Bank : Pendekatan Rasio NPL, LDR, 
BOPO DAN ROA Pada Bank Privat Dan Publik, 1-14.

Putra, A. D., \& Yusra, I. (2019). Peran profitabilitas dalam memoderasi pengaruh free cash flow terhadap kebijakan dividen di Indonesia. INA-Rxiv.

Suhartono, \& Yusra, I. (2019). Analisis perbandingan kinerja keuangan bank konvensional dengan bank syariah yang terdaftar di BEI. INA-Rxiv, 1-9.

Ulya, N. I. (2014). EARNINGS DAN CAPITAL PRODI KEUANGAN ISLAM FAKULTAS SYARI ' AH DAN HUKUM UNIVERSITAS ISLAM NEGERI SUNAN KALIJAGA.

Yusra, I. (2016). Kemampuan Rasio Likuiditas dan Solvabilitas dalam Memprediksi Laba Perusahaan: Studi Empiris pada Perusahaan Telekomunikasi yang Terdaftar di Bursa Efek Indonesia. Jurnal Benefita, 1(1), 33-42. https://doi.org/http://dx.doi.org/10.22216/jbe.v1i1.878

Yusra, I., Hadya, R., \& Fernandes, J. (2017). Likuiditas , financial leverage , dan prediktabilitas beta: pendekatan Fowler and Rorke sebagai metode koreksi Beta. Jurnal Benefita, 2(1), 81-91.

Ari, \& Setyaningsih. (2013). Analisis Perbandingan Kinerja Keuangan Perbankan Syariah Dengan Perbankan Konvensional, 13(1), 100-115.

Bambang Sudiyatno, J. S. (2008). Analisis Pengaruh Dana Pihak Ketiga, BOPO, CAR, Dan LDR Terhadap Kinerja Keuangan Pada Sektor Perbankan Yang Go Public Di Bursa Efek Indonesi, 2, 125-137.

Eko, Sri, D. (2014). Analisis Posisi Kinerja Keuangan Antara Bank Syariah dan Bank Konvensional Di Indonesia, 2(4), 258-268.

Marissa Ardiyana. (2011). KEUANGAN BANK SYARI’'AH DAN BANK KONVENSIONAL SEBELUM, SELAMA, DAN.

Mulfita, A., \& Yusra, I. (2019). Analisis regresi data panel terhadap likuiditas saham di Indonesia. INA-Rxiv.

Ningsih, widya wahyu. (2012). Analisis perbandingan kinerja keuangan bank umum syariah dengan bank umum konvensional di indonesia skripsi.

Nuresya Meliyanti. (2008). Analisis Kinerja Keuangan Bank : Pendekatan Rasio NPL, LDR, BOPO DAN ROA Pada Bank Privat Dan Publik, 1-14.

Putra, A. D., \& Yusra, I. (2019). Peran profitabilitas dalam memoderasi pengaruh free cash flow terhadap kebijakan dividen di Indonesia. INA-Rxiv.

Suhartono, \& Yusra, I. (2019). Analisis perbandingan kinerja keuangan bank konvensional dengan bank syariah yang terdaftar di BEI. INA-Rxiv, 1-9.

Ulya, N. I. (2014). EARNINGS DAN CAPITAL PRODI KEUANGAN ISLAM FAKULTAS SYARI' AH DAN HUKUM UNIVERSITAS ISLAM NEGERI SUNAN KALIJAGA.

Yusra, I. (2016). Kemampuan Rasio Likuiditas dan Solvabilitas dalam Memprediksi Laba 
Perusahaan: Studi Empiris pada Perusahaan Telekomunikasi yang Terdaftar di Bursa Efek Indonesia. Jurnal Benefita, 1(1), 33-42.

https://doi.org/http://dx.doi.org/10.22216/jbe.v1i1.878

Yusra, I., Hadya, R., \& Fernandes, J. (2017). Likuiditas , financial leverage , dan prediktabilitas beta: pendekatan Fowler and Rorke sebagai metode koreksi Beta. Jurnal Benefita, 2(1), 81-91.

Ari, \& Setyaningsih. (2013). Analisis Perbandingan Kinerja Keuangan Perbankan Syariah Dengan Perbankan Konvensional, 13(1), 100-115.

Bambang Sudiyatno, J. S. (2008). Analisis Pengaruh Dana Pihak Ketiga, BOPO, CAR, Dan LDR Terhadap Kinerja Keuangan Pada Sektor Perbankan Yang Go Public Di Bursa Efek Indonesi, 2, 125-137.

Eko, Sri, D. (2014). Analisis Posisi Kinerja Keuangan Antara Bank Syariah dan Bank Konvensional Di Indonesia, 2(4), 258-268.

Marissa Ardiyana. (2011). KEUANGAN BANK SYARI’'AH DAN BANK KONVENSIONAL SEBELUM, SELAMA, DAN.

Mulfita, A., \& Yusra, I. (2019). Analisis regresi data panel terhadap likuiditas saham di Indonesia. INA-Rxiv.

Ningsih, widya wahyu. (2012). Analisis perbandingan kinerja keuangan bank umum syariah dengan bank umum konvensional di indonesia skripsi.

Nuresya Meliyanti. (2008). Analisis Kinerja Keuangan Bank : Pendekatan Rasio NPL, LDR, BOPO DAN ROA Pada Bank Privat Dan Publik, 1-14.

Putra, A. D., \& Yusra, I. (2019). Peran profitabilitas dalam memoderasi pengaruh free cash flow terhadap kebijakan dividen di Indonesia. INA-Rxiv.

Suhartono, \& Yusra, I. (2019). Analisis perbandingan kinerja keuangan bank konvensional dengan bank syariah yang terdaftar di BEI. INA-Rxiv, 1-9.

Ulya, N. I. (2014). EARNINGS DAN CAPITAL PRODI KEUANGAN ISLAM FAKULTAS SYARI ' AH DAN HUKUM UNIVERSITAS ISLAM NEGERI SUNAN KALIJAGA.

Yusra, I. (2016). Kemampuan Rasio Likuiditas dan Solvabilitas dalam Memprediksi Laba Perusahaan: Studi Empiris pada Perusahaan Telekomunikasi yang Terdaftar di Bursa Efek Indonesia. Jurnal Benefita, 1(1), 33-42. https://doi.org/http://dx.doi.org/10.22216/jbe.v1i1.878

Yusra, I., Hadya, R., \& Fernandes, J. (2017). Likuiditas , financial leverage , dan prediktabilitas beta: pendekatan Fowler and Rorke sebagai metode koreksi Beta. Jurnal Benefita, 2(1), 81-91.

Ari, \& Setyaningsih. (2013). Analisis Perbandingan Kinerja Keuangan Perbankan Syariah Dengan Perbankan Konvensional, 13(1), 100-115.

Bambang Sudiyatno, J. S. (2008). Analisis Pengaruh Dana Pihak Ketiga, BOPO, CAR, Dan LDR Terhadap Kinerja Keuangan Pada Sektor Perbankan Yang Go Public Di Bursa 
Efek Indonesi, 2, 125-137.

Eko, Sri, D. (2014). Analisis Posisi Kinerja Keuangan Antara Bank Syariah dan Bank Konvensional Di Indonesia, 2(4), 258-268.

Marissa Ardiyana. (2011). KEUANGAN BANK SYARI' AH DAN BANK KONVENSIONAL SEBELUM, SELAMA, DAN.

Mulfita, A., \& Yusra, I. (2019). Analisis regresi data panel terhadap likuiditas saham di Indonesia. INA-Rxiv.

Ningsih, widya wahyu. (2012). Analisis perbandingan kinerja keuangan bank umum syariah dengan bank umum konvensional di indonesia skripsi.

Nuresya Meliyanti. (2008). Analisis Kinerja Keuangan Bank : Pendekatan Rasio NPL, LDR, BOPO DAN ROA Pada Bank Privat Dan Publik, 1-14.

Putra, A. D., \& Yusra, I. (2019). Peran profitabilitas dalam memoderasi pengaruh free cash flow terhadap kebijakan dividen di Indonesia. INA-Rxiv.

Suhartono, \& Yusra, I. (2019). Analisis perbandingan kinerja keuangan bank konvensional dengan bank syariah yang terdaftar di BEI. INA-Rxiv, 1-9.

Ulya, N. I. (2014). EARNINGS DAN CAPITAL PRODI KEUANGAN ISLAM FAKULTAS SYARI ' AH DAN HUKUM UNIVERSITAS ISLAM NEGERI SUNAN KALIJAGA.

Yusra, I. (2016). Kemampuan Rasio Likuiditas dan Solvabilitas dalam Memprediksi Laba Perusahaan: Studi Empiris pada Perusahaan Telekomunikasi yang Terdaftar di Bursa Efek Indonesia. Jurnal Benefita, 1(1), 33-42. https://doi.org/http://dx.doi.org/10.22216/jbe.v1i1.878

Yusra, I., Hadya, R., \& Fernandes, J. (2017). Likuiditas , financial leverage , dan prediktabilitas beta: pendekatan Fowler and Rorke sebagai metode koreksi Beta. Jurnal Benefita, 2(1), 81-91. 